[Agr. Biol. Chem., Vol. 30, No. 4, p. 416 417, 1966]

\title{
Production of $\alpha$-Ketoglutaric Acid from Salicylic Acid by Bacteria
}

Sir:

It is known that salicylic acid is an intermediate of the oxidative degradation of naphthalene, phenanthrene and anthracene, and that it is transformed into catechol by microorganisms. $^{1 \sim 31}$ The production of $\alpha$-ketoglutaric acid as a metabolite of salicylic acid, however, has not yet been known.

The present paper briefly describes that $\alpha$ ketoglutaric acid (sometimes also pyruvic acid) was produced from salicylic acid by bacteria. Many strains which utilized salicylic acid as a sole carbon source were isolated from soil and other natural materials. The isolated bacterial strains produced a large amount of keto acids in the culture fluid as shown in Table I. Strain K102 was grown in the
( $\mathrm{pH} 7.0)$. Cultivation was performed on the reciprocal shaker ( 130 strokes per min.) at $28^{\circ} \mathrm{C}$. After 28 hours, the cells were removed by centrifugation. Residual salicylic acid was precipitated by acidification with sulfuric acid. The filtrate was concentrated to a small volume under the reduced pressure at $40^{\circ} \mathrm{C}$. The keto acid in the concentrate was extracted with ether. The solvent was evaporated, and about $100 \mathrm{mg}$ of the keto acid (crude) was obtained, which was isolated in the crystalline form as 2, 4-dinitrophenylhydrazone. Paper chromatography of this crystal showed only one spot corresponding to 2, 4-dinitrophenylhydrazone of $\alpha$-ketoglutaric acid. Its melting point was $220^{\circ} \mathrm{C}$, and not depressed by mixing with the authentic

Table I. Production of Keto Acids from Salicylic acid by Bacterial Strains*

\begin{tabular}{lcc} 
Strain No. & \multicolumn{2}{c}{ Salicylic acid } \\
added & $\begin{array}{c}\text { consumed } \\
(\mathrm{mg} / \mathrm{ml} / \mathrm{ml})\end{array}$ \\
$\mathrm{K} 62$ & 10.0 & 9.67 \\
$\mathrm{~K} 361$ & 10.0 & 9.90 \\
$\mathrm{~K} 132-2$ & 10.0 & 9.87 \\
$\mathrm{~K} 102$ & 10.0 & 9.56 \\
$\mathrm{~K} 142$ & 10.0 & 8.22 \\
$\mathrm{~K} 362$ & 10.0 & 10.0 \\
$\mathrm{~K} 221$ & 10.0 & 7.34
\end{tabular}

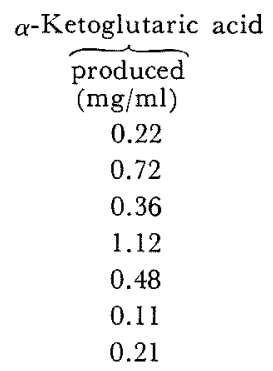

$\begin{gathered}\text { Produced } \\ (\mathrm{mg} / \mathrm{ml})\end{gathered}$
0.00
0.00
0.00
0.00
0.52
1.87
0.29

* Bacterial strains were grown for $24 \sim 30$ hours.

medium consisting of salicylic acid $1.0 \mathrm{~g}$, $\left(\mathrm{NH}_{4}\right)_{2} \mathrm{SO}_{4} 0.1 \mathrm{~g}, \mathrm{~K}_{2} \mathrm{HPO}_{4} 0.2 \mathrm{~g}, \mathrm{KH}_{2} \mathrm{PO}_{4} 0.1 \mathrm{~g}$, $\mathrm{MgSO}_{4} \cdot 7 \mathrm{H}_{2} \mathrm{O} \quad 0.05 \mathrm{~g}$ and tap water $100 \mathrm{ml}$

1) R.J. Strawinski and R.W. Stone, J. Bacteriol., 45, 16 (1943).

2) R. E. Klausmeier and R. J. Strawinski, ibid., 73, 461 (1957).

3) M. H. Rogoff and I. Wender, ibid., 74, 108 (1957). specimen. The hydrogenation of it gave glutamic acid, which was identified chromatographically. ${ }^{4)}$ Its infrared spectrum was identical with that of the authentic specimen as shown in Fig. 1. On the other hand,

\footnotetext{
4) M. Alfthan and A. L. Virtanen, Acta. Chem. Scand,,9, 186 (1955).
} 
when strain K362 was grown in the same medium as mentioned above, pyruvic and $\alpha$ -

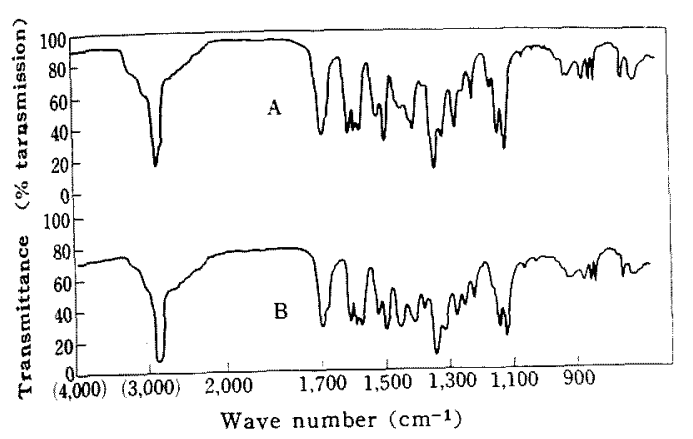

FIG. 1. Infrared Spectra of 2, 4-Dinitrophenylhydrazone of $\alpha$-Ketoglutaric acid (Nujol Mull).

A: authentic specimen

B: 2,4-dinitrophenylhydrazone of keto acid isolated. ketoglutaric acids were simultaneously produced. The taxonomical characteristics of the bacterial strains isolated and the mechanism of the production of these keto acids are under investigation.

We wish to express our thanks to Prof. M. Nakajima, Kyoto University, for the infrared spectral analysis.

\section{Koichi Ogata \\ Masahiro OsUGI}

Department of Agricultural Chemistry, Faculty of Agriculture, Kyoto University, Kyoto.

Received January 29, 1966 